\title{
Purification and immunochemical characterization of a male-specific rat liver oestrogen sulphotransferase
}

\author{
Emma B. BORTHWICK, ${ }^{\star} \dagger$ Ann BURCHELL $†$ and Michael W. H. COUGHTRIE $\ddagger$ \\ Departments of *Biochemical Medicine and †Obstetrics and Gynaecology, University of Dundee, Ninewells Hospital and Medical School, \\ Dundee DD1 9SY, Scotland, U.K.
}

Sulphation of oestrogens represents an important regulatory mechanism for these biologically active compounds. We have characterized and purified a form of rat liver sulphotransferase (ST), existing as a $32500 \mathrm{Da}$ monomer, which sulphates oestrogens, and have used this preparation to produce antibodies against oestrogen ST. The enzyme was active against oestrone, oestriol and $\beta$-oestradiol, but not towards androgens. Using the antibody as a probe for immunoblotting, it was determined that the enzyme is expressed solely in male rats, and predominantly in the liver. Of the tissues examined, the only major extrahepatic tissue found to have any oestrogen ST was the brain (although the levels were very low), indicating that there might be a role for the sulphation of oestrogens in the brain. Examination of human liver and platelet cytosols by immunoblotting showed that the antibody recognized two major proteins of 32 and $34 \mathrm{kDa}$, which were presumed to correspond to the two principal phenol ST isoenzymes present in man.

\section{INTRODUCTION}

Sulphation is a major pathway in the metabolism of steroid hormones (Hobkirk, 1985), and in rats there are numerous steroid sulphotransferases (STs) which can be distinguished by their sex-specific expression and their behaviour on ion-exchange and gel-filtration chromatography (e.g. Singer et al., 1976, 1982; Singer, 1978; Jakoby et al., 1980; Sugiyama et al., 1984; Hobkirk, 1985). The isolation of rat cDNA clones representing two very closely related hydroxysteroid STs (Ogura et al., 1989a,b) and a phenol ST (Ozawa et al., 1990) has provided sequence information demonstrating that the steroid STs belong to a different subfamily from the phenol STs. The cloning of an oestrogen ST cDNA from bovine placenta (Moore et al., 1988) suggested that this enzyme was part of another ST subfamily, since it shared only about $50 \%$ amino acid sequence similarity with the steroid and phenol STs isolated to date.

Although much is known of the biochemistry of phenol and hydroxysteroid STs, there is a paucity of information on the enzyme(s) involved in the sulphation of oestrogens [early work has been reviewed by Jakoby et al. (1980) and Hobkirk (1985)]. The enzyme appears to be important in reproductive/ developmental tissues, and has been studied in placenta (Nash et al., 1988), chorion (Bartlett and Hobkirk, 1991), endometrium (Saunders et al., 1989) and testes (Hobkirk et al., 1989). Additionally, Hobkirk's group has determined that, in the guinea pig adrenal gland, there are separate STs for the sulphation of oestrogens and hydroxysteroids such as pregnenolone (Hobkirk et al., 1990). The main oestrogen ST in rat liver appears to exist as a monomeric enzyme of approx. $32500 \mathrm{Da}$, a somewhat unusual observation since STs tend to exist as multimeric proteins. Takikawa et al. (1986) isolated a ST from male rat liver which sulphated $\beta$-oestradiol and which was also active with bile acids; however, little further information is available as to the properties of this enzyme. We have therefore performed a comprehensive characterization of a male-specific enzyme which sulphates oestrone and other oestrogens, including a method for the rapid isolation of significant quantities of the protein, the production of polyclonal anti-(oestrogen ST) antibodies and the examination of the expression of this protein in various rat and human tissues.

\section{MATERIALS AND METHODS}

\section{Chemicals}

[2,4,6,7- $\left.{ }^{3} \mathrm{H}(\mathrm{n})\right]$ Oestrone $(90.5 \mathrm{Ci} / \mathrm{mmol}),\left[2,4,6,7-{ }^{3} \mathrm{H}\right.$ (n)oestradiol (87.6 Ci/mmol), [2,4,6,7- $\left.{ }^{3} \mathrm{H}(\mathrm{n})\right]$ oestriol $(91.1 \mathrm{Ci} / \mathrm{mmol}),[1,2,6,7-$ $\left.{ }^{3} \mathrm{H}(\mathrm{n})\right]$ testosterone $\quad(87.1 \mathrm{Ci} / \mathrm{mmol}), \quad\left[7-{ }^{3} \mathrm{H}(\mathrm{n})\right]$ pregnenolone $(25 \mathrm{Ci} / \mathrm{mmol})$ and $\left[1,2,6,7-{ }^{3} \mathrm{H}(\mathrm{n})\right]$ dehydroepiandrosterone $(114.7 \mathrm{Ci} / \mathrm{mmol})$ were purchased from Du Pont/NEN, Stevenage, U.K., and $1-\left[1-{ }^{14} \mathrm{C}\right]$ naphthol $(53 \mathrm{mCi} / \mathrm{mmol})$ was from Amersham U.K. Ltd. 3'-Phosphoadenosine 5'phosphosulphate (PAPS) and all chromatography media were obtained from Pharmacia, Milton Keynes, U.K., and 1-naphthol was obtained from Merck, Glasgow, U.K. Goat anti-rabbit IgG, NitroBlue Tetrazolium, 5-bromo-4-chloro-3-indolyl phosphate ( $p$-toluidine salt), Freund's complete and incomplete adjuvants and unlabelled steroids were purchased from Sigma Chemical Co., Poole, Dorset, U.K. Scintillation fluid (Emulsifier Safe) was from Canberra Packard, Pangbourne, U.K., and all other reagents were of analytical grade and were purchased from commonly used local suppliers.

\section{Tissue preparation}

Adult (> 12 weeks; 250-300 g) Wistar rats were used throughout, and were from the colony maintained in this Institute. Adult human liver samples (histologically normal) were obtained from patients (age and sex not known) undergoing surgical resection for the treatment of metastatic cancer of the liver, and human platelets were prepared from healthy adult male volunteers. Tissue cytosols were prepared by differential centrifugation.

Abbreviations used: ST, sulphotransferase; PST, phenol sulphotransferase; P-PST, phenol-metabolizing form of PST; M-PST, monoaminemetabolizing form of PST; PAPS, 3'-phosphoadenosine 5'-phosphosulphate; DHEA, dehydroepiandrosterone.

$\ddagger$ To whom correspondence should be addressed. 
Homogenates $(30 \%$, w/v) were prepared in $10 \mathrm{mM}$ Tris $/ \mathrm{HCl}$, $\mathrm{pH} 7.4,250 \mathrm{mM}$ sucrose and $3 \mathrm{mM}$ 2-mercaptoethanol (buffer A) and centrifuged at $10000 \mathrm{~g}$ for $15 \mathrm{~min}$, whereupon the resulting supernatants were subjected to further centrifugation at $105000 \mathrm{~g}$ for $60 \mathrm{~min}$. The supernatants were aspirated carefully, avoiding the lipid layer at the surface, and either used immediately (for protein purification) or divided into $1 \mathrm{ml}$ aliquots and stored at $-70^{\circ} \mathrm{C}$ until used (within 3 months). All handling of tissue was done at $0-4{ }^{\circ} \mathrm{C}$.

\section{Enzyme assays}

ST assays were performed using methods previously described (Coughtrie and Sharp, 1990; Coughtrie et al., 1990), with the following exceptions. Oestrone ST was assayed in a final volume of $200 \mu \mathrm{l}$ containing $7.5 \mu \mathrm{M}\left[{ }^{3} \mathrm{H}\right]$ oestrone $(0.1 \mu \mathrm{Ci}), 50 \mu \mathrm{M}$ PAPS and $625 \mu \mathrm{g}$ of rat liver cytosol in a buffer of $50 \mathrm{mM}$ potassium phosphate, $\mathrm{pH} 5.5$, and $2.5 \mathrm{mM} \mathrm{MgCl}$. After incubation for $20 \mathrm{~min}$, the reaction was stopped by the addition of $3 \mathrm{ml}$ of water-saturated dichloroethane, followed by $300 \mu \mathrm{l}$ of water. After vigorous shaking for $2 \mathrm{~min}$, the phases were separated by centrifugation at $3000 \mathrm{~g}$ for $3 \mathrm{~min}$. An aliquot $(200 \mu \mathrm{l})$ of the aqueous phase was subjected to liquid scintillation spectrometry. The same conditions were employed for male and female rat liver cytosol.

The incubation for the assay of ST activity towards $\beta$ oestradiol in male rat liver comprised $10 \mu \mathrm{M} \beta$-oestradiol $(0.1 \mu \mathrm{Ci}), 50 \mu \mathrm{M}$ PAPS and $250 \mu \mathrm{g}$ of cytosolic protein, in the above buffer, and the same protocol as used for oestrone ST was followed. For female rat liver, the concentration of $\beta$-oestradiol used was $20 \mu \mathrm{M}$.

Oestriol sulphation in male rat liver was assessed using $5 \mu \mathrm{M}$ $\left[{ }^{3} \mathrm{H}\right.$ ]oestriol $(0.1 \mu \mathrm{Ci}), 50 \mu \mathrm{M}$ PAPS and $100 \mu \mathrm{g}$ of rat liver cytosolic protein in the same buffer as used for the oestrone ST assay. Following a $20 \mathrm{~min}$ incubation at $37^{\circ} \mathrm{C}$, the reaction was terminated by the addition of $3 \mathrm{ml}$ of ethyl acetate, and the same procedure as used for oestrone ST was adopted. For the assay of oestriol ST in female rat liver, the concentrations of $\left[{ }^{3} \mathrm{H}\right]$ oestriol and PAPS were $20 \mu \mathrm{M}(0.1 \mu \mathrm{Ci})$ and $25 \mu \mathrm{M}$ respectively, and $200 \mu \mathrm{g}$ of cytosolic protein was used.

Testosterone ST was assayed using the same method as for oestrone ST, with the exception that $10 \mu \mathrm{M}\left[{ }^{3} \mathrm{H}\right]$ testosterone $(0.1 \mu \mathrm{Ci})$ and $150 \mu \mathrm{g}$ of cytosolic protein were used.

Pregnenolone ST was assayed as for oestrone ST, except that for male rat liver the concentration of $\left[{ }^{3} \mathrm{H}\right]$ pregnenolone was $5 \mu \mathrm{M}(0.1 \mu \mathrm{Ci})$ and $200 \mu \mathrm{g}$ of cytosolic protein was used, and for females $10 \mu \mathrm{M}\left[{ }^{3} \mathrm{H}\right]$ pregnenolone and $150 \mu \mathrm{g}$ of cytosolic protein were used. These conditions were adopted after extensive optimization of all these assay methods with respect to substrate and PAPS concentrations, $\mathrm{pH}$, cytosolic protein content and incubation time.

\section{Resolution of cytosolic steroid ST activities by gel-filtration chromatography}

Cytosolic fractions $(5 \mathrm{ml})$ of male and female rat liver [prepared as above, except that $50 \%(\mathrm{w} / \mathrm{v})$, homogenates were used] were loaded directly on to a column $(90 \mathrm{~cm} \times 2.6 \mathrm{~cm})$ of Sephacryl S$200 \mathrm{HR}$, pre-equilibrated in buffer A containing $100 \mathrm{mM} \mathrm{NaCl}$, at a flow rate of $20 \mathrm{ml} / \mathrm{h}$. The eluted proteins were collected in fractions of $3 \mathrm{ml}$, and the sulphation of a range of compounds in selected fractions was determined as described above. The protein content of the eluate was continuously monitored by measuring the $A_{280}$.

\section{Purlification of rat liver oestrogen ST}

Routinely, approx. $20 \mathrm{~g}$ of male rat liver was used to prepare a $30 \%(\mathrm{w} / \mathrm{v})$ homogenate as described above, and the cytosol processed from this homogenate was applied directly to a column of DEAE-Sepharose Fast Flow $(35 \mathrm{~cm} \times 2.6 \mathrm{~cm})$ at a flow rate of $60 \mathrm{ml} / \mathrm{h}$ in buffer A. Following elution of unbound material, a linear gradient was established between buffer $\mathbf{A}$ and buffer $\mathbf{A}$ containing $300 \mathrm{mM} \mathrm{NaCl}$, in a total volume of $1000 \mathrm{ml}$. Fractions of $7 \mathrm{ml}$ were collected and those fractions containing high oestrone ST activity were pooled, concentrated to approx. $5 \mathrm{ml}$ by ultrafiltration in a stirred cell (Amicon) and applied at a flow rate of $20 \mathrm{ml} / \mathrm{h}$ to a column of Sephacryl S-200 HR $(90 \mathrm{~cm} \times 2.6 \mathrm{~cm})$ pre-equilibrated with buffer $\mathrm{A}$ containing $100 \mathrm{mM} \mathrm{NaCl}$. Fractions of $3 \mathrm{ml}$ were collected and assayed for oestrone ST enzyme activity, and those fractions exhibiting high activity and which were well resolved from other ST activities [towards dehydroepiandrosterone (DHEA) and 1-naphthol] were pooled, concentrated to $5 \mathrm{ml}$ and desalted using pre-packed Sephadex G-25 columns (PD10, Pharmacia). Aliquots of $2 \mathrm{ml}$ of this material were applied to a column of ADP-agarose $(1.6 \mathrm{~cm} \times 5 \mathrm{~cm})$ equilibrated in buffer $A$ at a flow rate of $20 \mathrm{ml} / \mathrm{h}$, and $1 \mathrm{ml}$ fractions were collected. Following the elution of unbound protein, the column was washed with buffer A containing $50 \mathrm{mM} \mathrm{NaCl}$ to remove any non-specifically bound protein, and oestrone ST was eluted by applying $5 \mathrm{ml}$ of $100 \mu \mathrm{M}$ PAPS in buffer A containing $50 \mathrm{mM} \mathrm{NaCl}$. Fractions containing oestrone ST activity were analysed by SDS/PAGE, and those containing only one silver-stained band were pooled, concentrated and stored at $-70^{\circ} \mathrm{C}$.

\section{Antibody production}

Pure oestrogen ST ( $150 \mu \mathrm{g}$ in a volume of $1 \mathrm{ml})$ was mixed with an equal volume of Freund's complete adjuvant and used to immunize an adult female New Zealand White rabbit by a combination of intramuscular and intradermal injections. After 4 weeks, an additional $150 \mu \mathrm{g}$ of purified enzyme was mixed with Freund's incomplete adjuvant, and the immunization procedure was repeated. A further two sets of booster injections, each of $150 \mu \mathrm{g}$ of oestrogen ST and performed 4 weeks apart, were administered and the antiserum was collected 14 days after the fourth immunization by cardiac puncture under terminal barbiturate anaesthesia. Antibody production was monitored at 4-weekly intervals using immunoblot analysis with purified oestrogen ST and rat liver cytosol. The IgG fraction of the antiserum was enriched by precipitation with saturated ammonium sulphate to achieve $50 \%$ saturation, followed by extensive dialysis against $100 \mathrm{mM}$ sodium phosphate buffer, $\mathrm{pH}$ 7.4. This crude IgG preparation was divided into $0.5 \mathrm{ml}$ aliquots and stored at $-70^{\circ} \mathrm{C}$. For immunoblotting experiments involving human tissue, the anti-(oestrogen ST) IgG was adsorbed against human serum proteins immobilized on cyanogen bromide-activated Sepharose 4B, in order to reduce the background staining which was observed against unrelated human proteins.

\section{SDS/PAGE and immunoblot analysis}

Proteins were resolved on denaturing SDS/polyacrylamide gels (11\% acrylamide monomer) according to the method first described by Laemmli (1970), and silver-stained (Merril et al., 1981). For immunoblotting experiments, the staining was omitted and proteins were electrophoretically transferred to nitrocellulose sheets (Schleicher \& Schuell) as described by Towbin et al. (1979). Immunochemical localization of oestrogen ST was 
performed by the alkaline phosphatase method as previously described (Coughtrie et al., 1988), with the one exception that the $\mathrm{pH}$ of the buffer used for all incubation and washing steps was 9.0. All electrophoresis and blotting apparatus was from Hoefer Scientific Instruments, Newcastle-under-Lyme, U.K.

\section{Protein determination}

Protein was estimated by the method of Lowry et al. (1951) with BSA as standard, with the exception of highly purified preparations of oestrogen ST where the method of Bradford (1976) was used, again with BSA as standard.

\section{RESULTS}

\section{ST activities in male and female rats}

The sulphation of oestrogens and a variety of other steroid and xenobiotic substrates by male and female rat liver cytosols was examined (Table 1). The sulphation of oestrone and oestriol was greater in male rats, with oestriol ST having the highest male/female activity ratio of 21 . The activity for $\beta$-oestradiol, when measured by this method, appeared to be higher in female rats (male/female ratio $=0.57$ ), although there was a wide variability in the individual measurements, and therefore oestrone and oestriol were used as substrates for the further characterization of this enzyme activity. The female-specific expression of the ST(s) responsible for the sulphation of DHEA and other hydroxysteroids was also demonstrated in these experiments, as was the higher phenol ST (PST) activity in male rats.

In order to investigate further the basis of these sex differences in ST activities, we subjected aliquots of male and female rat liver cytosol to gel-filtration analysis on a column of Sephacryl S-200 $\mathrm{HR}$, and assayed the resulting fractions for a range of ST enzyme activities. Figure 1 shows the results of these chromatographic separations, and demonstrates that in male rat liver cytosol (Figure 1a), the activity towards oestrone and oestriol was eluted last from the column, between fractions 90 and 95 . It was well separated from the activity towards the phenolic substrate 1naphthol (detected over a large range of fractions, suggesting that the numerous PSTs for which this compound is a substrate exhibit different molecular masses on gel filtration analysis) and from the small amount of DHEA ST activity in fractions 75-80. There was some oestrogen ST activity which appeared to coincide with the tail end of the 1-naphthol ST activity between fractions 80 and 90 , possibly indicating a degree of overlapping substrate specificity for these compounds with other ST isoenzymes. The experiment was then repeated with female rat liver cytosol (Figure 1b). No peak of oestrogen ST activity was demonstrated at fractions 90-95, and only a small amount of oestriol ST activity was evident around fraction 75 . The main peak of DHEA ST activity was eluted early from the column, between fractions 60 and 70, but seemed to spread further through the separation, up to fraction 80 . Overall, these data served to confirm that there is a male-specific oestrogen ST, which is readily separated from other ST activities in male rat liver cytosol by gel filtration. This therefore suggested a strategy for purifying this enzyme.

\section{Purlication of oestrogen ST from male rat liver}

The results of a typical protein purification experiment in which oestrogen ST was isolated from male rat liver are shown in Table
2. The activities towards oestrone and oestriol co-purified during this procedure, unlike 1-naphthol ST activity, which was present in the final preparation at roughly the same level as in the cytosol, suggesting that the oestrogen ST demonstrates a small degree of overlapping substrate specificity towards planar phenolic compounds. The purified preparation did not show any DHEA ST activity. The enzyme was markedly unstable following the affinity chromatography step, resulting in the low level of activity of the final preparation.

The purified enzyme was homogeneous as determined by silver

\section{Table 1 ST activities in male and female rat liver cytosols}

Enzyme activities were determined as described in the Materials and methods section, and were measured in liver cytosols prepared from three different male and female rats. Data are expressed as pmol/min per $\mathrm{mg}$ of cytosolic protein, and are given as means \pm S.D. $(n=3)$.

\begin{tabular}{|c|c|c|c|}
\hline \multirow[b]{2}{*}{ Substrate } & \multicolumn{2}{|c|}{$\begin{array}{l}\text { ST activity } \\
\text { (pmol/min per } \mathrm{mg} \text { ) }\end{array}$} & \multirow[b]{2}{*}{$\begin{array}{l}\text { Male/female } \\
\text { ratio }\end{array}$} \\
\hline & $\begin{array}{l}\text { Male } \\
\text { rat liver }\end{array}$ & $\begin{array}{l}\text { Female } \\
\text { rat liver }\end{array}$ & \\
\hline Oestrone & $60 \pm 4.5$ & $6.7 \pm 4.3$ & 9.0 \\
\hline$\beta$-Oestradiol & $43 \pm 9$ & $76 \pm 35$ & 0.57 \\
\hline Oestriol & $136 \pm 16$ & $6.4 \pm 3.3$ & 21.3 \\
\hline DHEA & $12 \pm 5.2$ & $185 \pm 10$ & 0.07 \\
\hline Pregnenolone & $19 \pm 7.5$ & $78 \pm 31$ & 0.24 \\
\hline Testosterone & $6 \pm 3.0$ & $26 \pm 18$ & 0.23 \\
\hline 1-Naphthol (pH 5.5) & $2880 \pm 193$ & $1344 \pm 219$ & 2.2 \\
\hline 1-Naphthol (pH 6.6) & $2143 \pm 166$ & $980 \pm 285$ & 2.2 \\
\hline
\end{tabular}

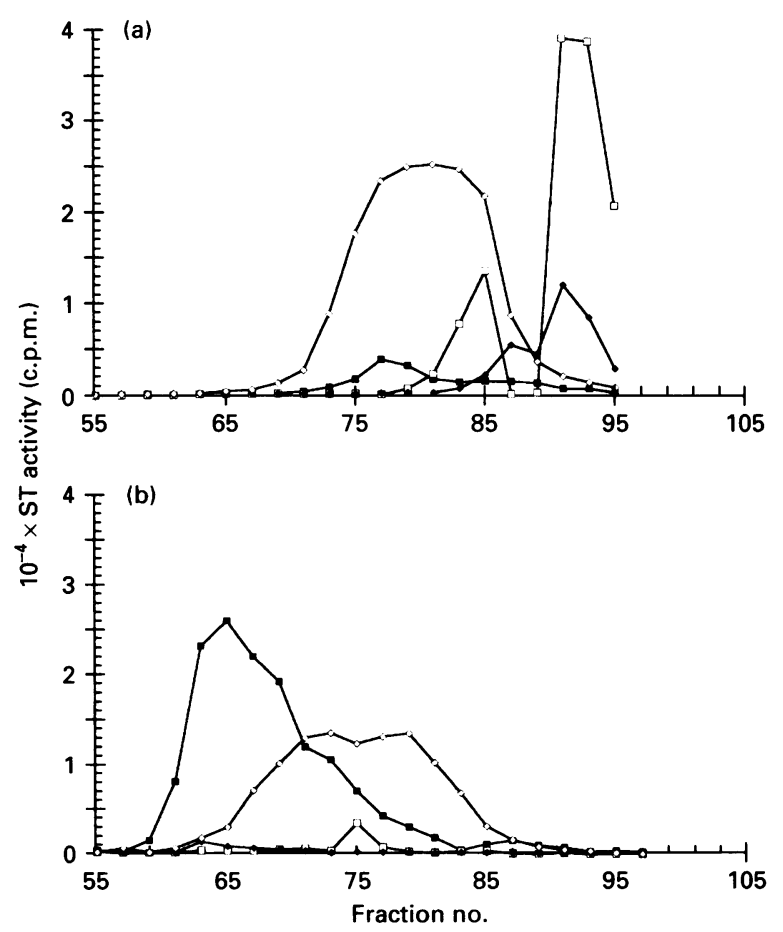

Figure 1 Gel-filtration chromatography of rat liver cytosol

Rat liver cytosol $(5 \mathrm{ml})$ from $50 \%$ (w/v) homogenates were applied directly to a column of Sephacryl S-200 as described in the Materials and methods section. Aliquots of fractions were assayed for the following substrates: 1-naphthol $(\diamond)$. DHEA $(\square)$, oestriol $(\square)$ and oestrone $(\diamond)$. (a) Male rat, (b) female rat. 
Table 2 Purification of rat liver oestrogen ST

\begin{tabular}{|c|c|c|c|c|c|}
\hline Purification step & $\begin{array}{l}\text { Total protein } \\
(\mathrm{mg})\end{array}$ & $\begin{array}{l}\text { Specific activity } \\
\text { (pmol/min per mg) }\end{array}$ & $\begin{array}{l}\text { Total activity } \\
\text { (nmol/min) }\end{array}$ & $\begin{array}{l}\text { Yield } \\
(\%)\end{array}$ & $\begin{array}{l}\text { Purification } \\
\text { (told) }\end{array}$ \\
\hline \multicolumn{6}{|l|}{ Oestrone } \\
\hline Cytosol & 2850 & 66 & 188.1 & 100 & 1 \\
\hline DEAE-Sepharose & 148.6 & 971 & 144.3 & 77 & 15 \\
\hline Sephacryl S-200 & 11.4 & 5231 & 59.5 & 32 & 79 \\
\hline ADP-agarose & 0.42 & 1624 & 0.682 & 0.4 & 25 \\
\hline \multicolumn{6}{|l|}{ Oestriol } \\
\hline Cytosol & 2850 & 130 & 370.5 & 100 & 1 \\
\hline DEAE-Sepharose & 148.6 & 1181 & 175.5 & 47 & 9 \\
\hline Sephacryl S-200 & 11.4 & 7360 & 83.7 & 23 & 56 \\
\hline ADP-agarose & 0.42 & 4213 & 1.77 & 0.5 & 32 \\
\hline \multicolumn{6}{|l|}{ 1-Naphthol } \\
\hline Cytosol & 2850 & 1972 & 5620 & 100 & 1 \\
\hline DEAE-Sepharose & 148.6 & 13787 & 2049 & 37 & 7 \\
\hline Sephacryl S-200 & 114 & 1579 & 18.0 & 0.3 & 0.8 \\
\hline ADP-agarose & 0.42 & 3500 & 1.47 & 0.03 & 1.7 \\
\hline
\end{tabular}

\section{Figure 2 SDS/PAGE of the purification of male rat liver oestrogen ST}

Samples were resolved on an SDS/polyacrylamide gel ( $11 \%$ acrylamide monomer) and silverstained. Lane 1, molecular mass markers; lane 2, male rat liver cytosol (5 $\mu \mathrm{g})$; lane 3, pooled protein from DEAE-Sepharose $(2.5 \mu \mathrm{g})$; lane 4, pooled protein from Sephacryl S-200 $(2.5 \mu \mathrm{g})$; lane 5, purified rat liver oestrogen ST $(1 \mu \mathrm{g})$.

staining following SDS/PAGE analysis (Figure 2), and the subunit molecular mass was $32500 \mathrm{Da}$ as determined from linear regression analysis using the molecular mass standards indicated in Figure 2. The molecular mass of the native protein was determined to be $32.5 \mathrm{kDa}$ by gel-filtration analysis on a Superose 12 column (results not shown) connected to a f.p.l.c. system (Pharmacia), indicating that this protein exists as a monomer. Attempts to obtain $\mathrm{N}$-terminal sequence data from the purified protein were unsuccessful, presumably as a result of blocking of the $\mathrm{N}$-terminus.

\section{Production and characterization of anti-(oestrogen ST) antibodies}

A total of $600 \mu \mathrm{g}$ of purified oestrogen ST was used to immunize a New Zealand White rabbit, and the resulting antiserum was characterized with respect to its inhibition of oestrogen ST activity in rat liver cytosol and its recognition of the purified enzyme on immunoblot analysis.

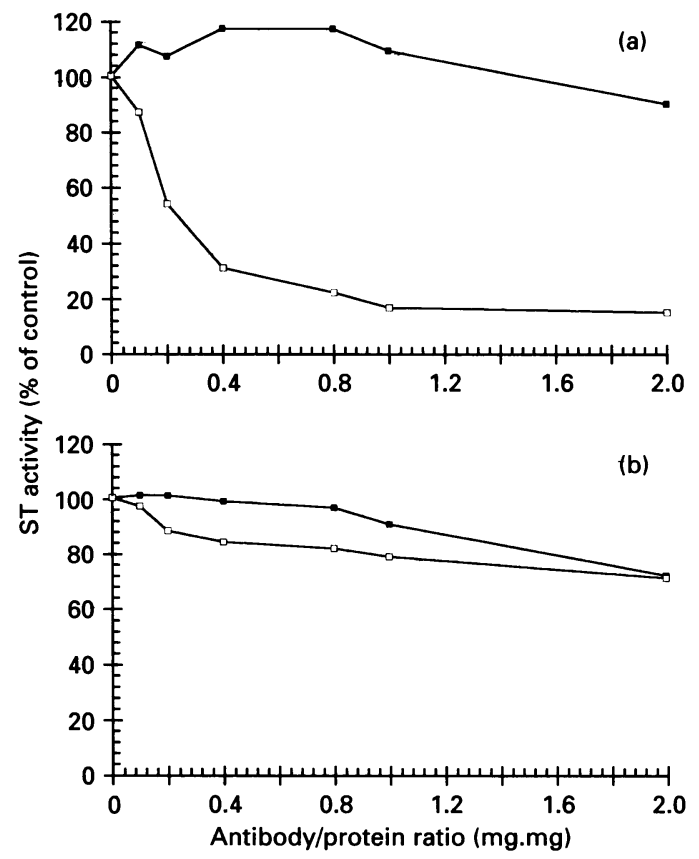

Figure 3 Inhibition of rat liver oestrone ST activity by anti-(rat liver oestrone ST) antibody

Aliquots of male (a) and female (b) rat liver cytosol were incubated with either pre-immune lgG ( $\square$ ) or anti-(oestrone ST) IgG ( $\square$ ) and assayed for oestrone ST activity as described in the Materials and methods section.

Figure 3 shows the inhibition of oestrone ST activities in male but not in female rat liver cytosol by the antibody preparation. Table 3 shows that the antibody also inhibited oestriol ST activity in male rat liver cytosol only, but was not able to inhibit DHEA or 1-naphthol ST activities in either male or female rat liver cytosol. This lack of inhibition of oestrogen ST activities in female liver is consistent with the idea that this antibody is specific for a form of ST which is expressed solely in male rats, and that the residual oestrogen ST activity observed in females (Table 1) is the result of the action of another ST isoenzyme(s). This notion was confirmed by immunoblot analysis of male and female rat liver cytosols using the anti-(oestrogen ST) antibody. 
Tabie 3 Inhibition of rat liver ST activities by anti-(oestrogen ST)

Data are means of duplicate experiments, and are expressed as percentages of the enzyme activity obtained in the absence of $\lg G$ in the incubation

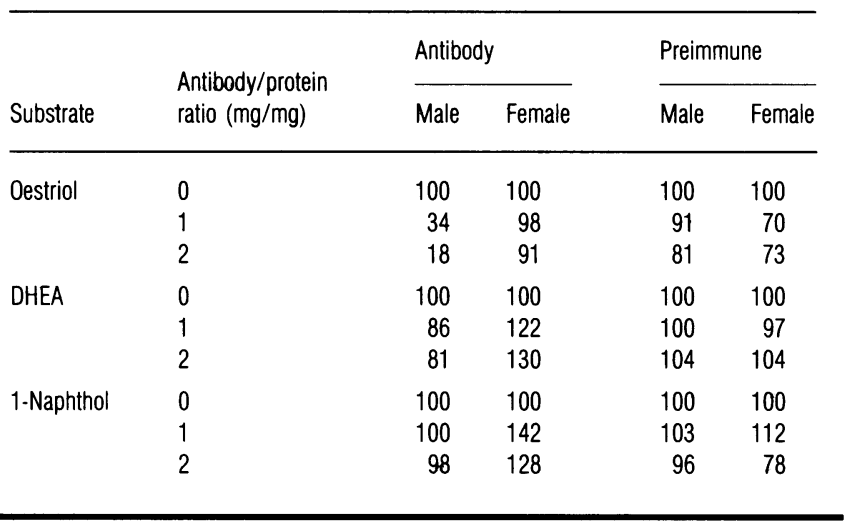

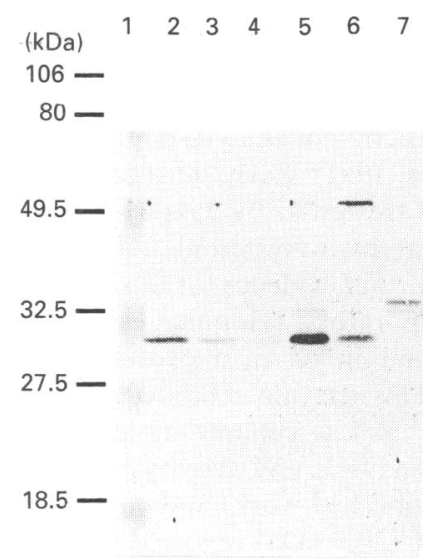

Figure 4 Immunoblot analysis of purified rat liver oestrogen ST and rat liver cytosol

Protein samples were subjected to electrophoresis on a polyacrylamide gel (11\% monomer) in the presence of $0.1 \%$ SDS, and following separation were electrophoretically transferred to nitrocellulose and immunostained as described in the Materials and methods section. Lane 1 , prestained molecular mass marker proteins; lanes 2-4, 100, 50 and $20 \mathrm{ng}$ of purified oestrogen ST respectively; lane $5,5 \mu \mathrm{g}$ of male rat liver cytosol; lane $6,2 \mu \mathrm{g}$ of male rat liver cytosol; lane $7,10 \mu \mathrm{g}$ of femate rat liver cytosol. Note that the prestained molecular mass markers used do not accurately represent the molecular masses of the standard proteins, and are therefore only used as a guide.

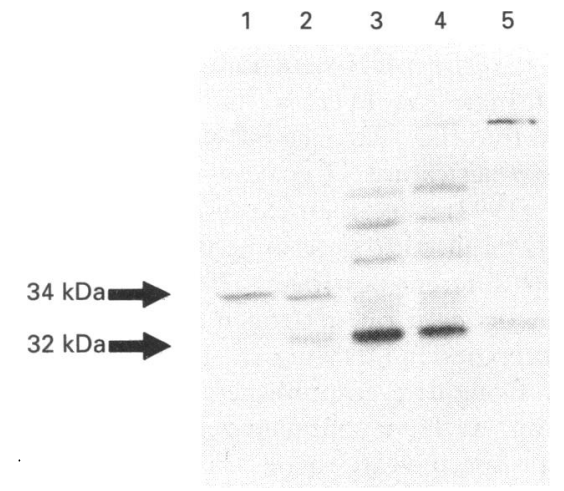

Figure 5 Immunoblot analysis of human liver and platelet cytosol

Immunoblot analysis was periormed as described in the legend to Figure 4. Lanes 1 and 2, $50 \mu \mathrm{g}$ of human platelet cytosol (from different individuals); lanes 3 and $4,20 \mu \mathrm{g}$ of human liver cytosol (from different individuals); lane $5 ; 2 \mu \mathrm{g}$ of male rat liver cytosol.

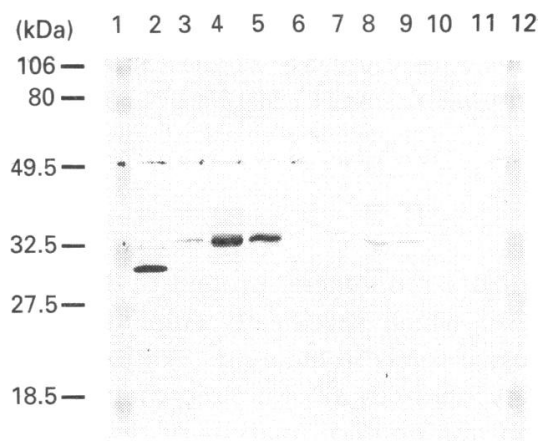

Figure 6 Tissue distribution of oestrogen ST in the rat

Immunoblot analysis was performed as described in the Materials and methods section. Lane 1, prestained molecular mass markers; lanes 2 and 3 , male and female rat liver cytosol respectively $(5 \mu \mathrm{g})$; lanes 4 and 5 , male and female rat kidney cytosol $(30 \mu \mathrm{g})$; lanes 6 and 7 , male and female rat lung cytosol $(50 \mu \mathrm{g})$; lanes 8 and 9 , male and female rat brain cytosol $(50 \mu \mathrm{g})$; lanes 10 and 11 , male and female rat intestine cytosol $(50 \mu \mathrm{g})$. Note that the prestained molecular mass markers used do not accurately represent the molecular masses of the standard proteins, and are therefore only used as a guide.

The antibody recognized the purified oestrogen ST, detecting an immunoreactive polypeptide of subunit molecular mass $32500 \mathrm{Da}$, and also recognized this protein in male liver cytosol. No such protein was detected in female liver cytosol (Figure 4), confirming that this ST is not expressed in female liver. [Note that the prestained molecular mass markers used in Figure 4, and also in Figure 5 (lane 1; Sigma), do not migrate at the exact molecular mass listed; however, when the molecular mass of the major polypeptide present in Figure 4, lanes 1-6, was calculated from a comparison with the mobilities of normal marker proteins electrophoresed on a second identical gel run at the same time and stained with Coomassie Blue, a value of $32.5 \mathrm{kDa}$ was obtained, which corresponds exactly to the molecular mass of the purified protein (not shown).] The antibody did recognize two proteins of approx. $35 \mathrm{kDa}$ in female rat liver cytosol, and it is possible that these represent related STs, although there was no cross-reaction with DHEA ST, which has a subunit molecular mass of approx. $30 \mathrm{kDa}$ (Ogura et al., 1990; S. Sharp and M. W. H. Coughtrie, unpublished work). When used to probe a Western blot of human liver and platelet cytosols (Figure 5), the antibody recognized one major protein of subunit molecular mass $32 \mathrm{kDa}$ in human liver, and two proteins of molecular mass 32 and $34 \mathrm{kDa}$ in human platelets. This was a very similar pattern of recognition to that reported by Roth's laboratory (Heroux et al., 1989) for an antibody raised against human platelet M-PST (i.e. monoamine-metabolizing form of PST), and suggests that this antibody recognizes both the phenolmetabolizing PST (P-PST; subunit molecular mass $32 \mathrm{kDa}$ ) and the M-PST (subunit molecular mass $34 \mathrm{kDa}$ ) present in man. A number of other apparently unrelated proteins were also recognized in human liver cytosol.

\section{Tissue distribution of oestrogen ST in rat tissues}

Immunoblot analysis of cytosols prepared from a range of male and female rat tissues showed that the $32 \mathrm{kDa}$ oestrogen ST polypeptide was expressed predominantly in male rat liver (Figure 6). Only male brain exhibited a lightly staining band at $32.5 \mathrm{kDa}$, which correlated with a small amount of oestrone ST activity (results not shown). The kidney showed strong staining of a polypeptide of approx. $34 \mathrm{kDa}$ (Figure 6, lanes 3 and 4), which did not exhibit any marked sex difference, and possibly represents 
a member of the PST family, since the rat kidney appears to be devoid of significant steroid ST activity (S. Sharp and M. W. H. Coughtrie, unpublished work; results not shown).

\section{DISCUSSION}

We have purified a monomeric protein of $32.5 \mathrm{kDa}$ from male rat liver cytosol which specifically sulphates oestrogens, and which is expressed solely in male rats. Antibodies raised against this protein recognized an immunoreactive polypeptide of $32.5 \mathrm{kDa}$ upon immunoblot analysis of male rat liver cytosol, which could not be detected in female rat liver and which, of the tissues examined, was expressed only in very small amounts in male rat brain. The antibody also recognized proteins of 32 and $34 \mathrm{kDa}$ in human liver and platelets, which presumably correspond to P-PST and M-PST respectively. The observation that the anti-(oestrogen ST) antibody preparation described here cross-reacted with proteins of 32 and $34 \mathrm{kDa}$ in human liver and platelet cytosol suggested that the antibody recognized the PPST and M-PST isoforms in human liver, and indeed the pattern of immunostaining was very similar to that described by Heroux et al. (1989), in Figure 3 of their paper, for an antibody raised against human platelet M-PST. Therefore our antibody should also prove useful in investigating PSTs, and therefore by association oestrogen ST, in man.

There remains some debate as to which ST isoenzyme(s) is responsible for the metabolism of oestrogens in man. The DHEA ST purified from human liver by Falany's group (Falany et al., 1989) exhibited only a small amount of activity towards oestrone and $\beta$-oestradiol, suggesting that this enzyme plays a minor role in the sulphation of oestrogens. However, a recent report from Weinshilboum's laboratory (Hernández et al., 1992) suggested that oestrone was predominantly sulphated by DHEA ST in human liver, and that $\beta$-oestradiol was predominantly sulphated by P-PST. There was, however, significant overlapping substrate specificity in the ability of P-PST and DHEA ST to sulphate these oestrogens, although it was apparent that M-PST was inactive against both compounds (Hernández et al., 1992). Recent work in this laboratory associated the metabolism of oestrone with that of the phenolic substrate 1-naphthol in human fetal lung, a tissue essentially devoid of DHEA ST activity (Jones et al., 1992), confirming the view that there is overlap in the substrate specificities of human STs towards oestrogens.

The oestrogen ST purified in this work is likely to be the equivalent of the enzyme reported by Kaplowitz's group (Sugiyama et al., 1984; Takikawa et al., 1986), who isolated a monomeric $32.5 \mathrm{kDa}$ protein metabolizing phenolic steroids. The present paper, however, describes a method for the isolation of this protein which is rapid (it can be accomplished in 3 days), technically straightforward and can produce significant quantities of the purified enzyme, in contrast to that described by Takikawa et al. (1986). The oestrogen ST is also likely to be different from the $\beta$-oestradiol ST described by Green and Singer (1983), since $\beta$-oestradiol ST does not exhibit the same sex difference as oestrone and oestriol ST, and did not apparently sulphate oestrone. In our hands, much of the $\beta$-oestradiol ST activity did co-elute with oestrone and oestriol ST activity on gel-filtration chromatography of male rat liver cytosol (results not shown); therefore $\beta$-oestradiol is a substrate for the oestrogen ST purified here. However, as a result of the lack of significant sex-specific expression of $\beta$-oestradiol ST activity, this substrate is also likely to be sulphated by another form of ST, which is distinct both from the oestrogen ST reported here and from hydroxysteroid ST (Green and Singer, 1983). It is for this reason that we restricted our analysis to oestrone and oestriol, since they appear to be much more specific substrates for the oestrogen ST investigated in the current work.

Oestrogen ST also appeared to be expressed primarily in the liver, with no immunoreactive protein being detectable in cytosols prepared from kidney, lung or intestine. Only the brain (male) demonstrated a very small amount of anti-(oestrogen ST) immunoreactive protein of the same mobility on SDS/PAGE as the oestrogen ST from male rat liver, suggesting that the brain may be a site of expression of oestrogen ST. The low level of protein (and of enzyme activity; results not shown) could be the result of specific sites of expression in the brain which would result in an effective dilution of the enzyme upon homogenization and preparation of cytosol from the whole brain. We are currently examining this possibility using immunohistochemical analysis.

The gel-filtration analysis performed during the course of this work also provided some information as to the possible basis for the sex difference in DHEA ST activity. The female rat has a 15fold higher hepatic DHEA ST activity than the male (Table 1), and it has been shown that, on immunoblot analysis of male and female rat liver cytosol (Ogura et al., 1989a; S. Sharp and M. W. H. Coughtrie, unpublished work), there is considerably less immunoreactive protein in the male. This has also been confirmed by Northern blot analysis (Ogura et al., 1989a; RungeMorris and Wilusz, 1991). Early purification work, particularly by Singer's group (reviewed by Jakoby et al., 1980), indicated that three different hydroxysteroid (i.e. DHEA) STs exist in female rat liver. Further evidence for this has come more recently from Matsui's laboratory (Homma et al., 1991) in a paper describing the isolation of an androsterone ST activity from female rat liver. This enzyme exhibited a wide range of native molecular masses and a subunit molecular mass of $30 \mathrm{kDa}$ [identical to that of a DHEA ST activity purified in this laboratory (Sharp et al., unpublished work) and very similar to that of the hydroxysteroid ST (30.5 kDa) reported by Ogura et al. (1990)]. When Homma et al. (1991) performed two-dimensional gel electrophoresis analysis on their purified androsterone ST, it was found to consist of three protein species, all of identical subunit molecular mass, but with differing pI values. It is therefore likely that the sex difference observed in the expression of hydroxysteroid ST in rats is in fact the result of the absence of at least one of these three proteins (from our analysis, probably that with the highest native molecular mass), whereas at least one remains, presumably at normal levels.

After this manuscript was submitted, we became aware of a paper reporting the isolation and expression of a cDNA clone encoding a rat liver oestrogen ST which metabolized $\beta$-oestradiol (Demyan et al., 1992). In that paper, Northern blot analysis demonstrated that the mRNA encoding this enzyme was present only in adult male rat liver, a finding consistent with our demonstration that the oestrogen ST was expressed only in male rat liver. Only $\beta$-oestradiol ST enzyme activity was measured by Demyan et al. (1992) using their expressed cDNA, and therefore further work is required to determine the substrate specificity of rat ST towards different oestrogens. This work is under way in our laboratory, using a rat oestrogen ST cDNA isolated using the antibody prepared in this work (E. B. Borthwick, A. Burchell and $\mathrm{M}$. W. H. Coughtrie, unpublished work).

In conclusion, we have characterized and purified a form of oestrogen ST specific to male rats, which is expressed predominantly in the liver. We have no evidence to suggest that this protein is expressed in female rats. An antibody preparation raised against this purified oestrogen $S T$ was used to investigate the tissue-specific expression of oestrogen ST in rats, and additionally was found to recognize two proteins in human tissue 
preliminarily identified as members of the PST family. This antibody preparation will therefore prove useful in investigating the function and regulation of oestrogen ST expression in rats, which appears to be strictly regulated at both sex and tissue levels, and will in addition find use as a probe for human PSTs.

This work was supported by grants from the Scottish Hospital Endowments Research Trust (to M.W.H.C. and A.B.) and from the Sir Jules Thorn Charitable Trust (to M.W.H.C.). We are grateful to Professor G. B. Odell for providing human liver samples, and to Alwen Jones for providing us with human platelet cytosol.

\section{REFERENCES}

Bartlett, N. R. and Hobkirk, R. (1991) J. Steroid Biochem. Mol. Biol. 38, 241-247 Bradford, M. M. (1976) Anal. Biochem. 72, 248-254

Coughtrie, M. W. H. and Sharp, S. (1990) Biochem. Pharmacol. 40, 2305-2313

Coughtrie, M. W. H., Burchell, B., Leakey, J. E. A. and Hume, R. (1988) Mol. Pharmacol.

34, 729-735

Coughtrie, M. W. H., Pears, J., Jones, A. L. and Burchell, A. (1990) Biochem. Pharmacol. 40, 2180-2183

Demyan, W. F., Song, C. S., Kim, D. S., Her, S., Gallwitz, W., Rao, T. E., Slomczynska, M., Chatterjee, B. and Roy, A. K. (1992) Mol. Endocrinol. 6, 589-597

Falany, C. N., Vasquez, M. E. and Kalb, J. N. (1989) Biochem. J. 260, 641-646

Green, J. M. and Singer, S. S. (1983) Can. J. Biochem. Cell Biol. 61, 15-22

Hernández, J. S., Watson, R. W., Wood, T. C. and Weinshilboum, R. M. (1992) Drug Metab. Dispos. 20, 413-422

Heroux, J. A., Falany, C. N. and Roth, J. A. (1989) Mol. Pharmacol. 36, 29-33

Hobkirk, R. (1985) Can. J. Biochem. Cell Biol. 63, 1127-1144

Hobkirk, R., Renaud, R. and Raeside, J. I. (1989) J. Steroid Biochem. 32, 387-392

Hobkirk, R., Glasier, M. A. and Brown, L. Y. (1990) Biochem. J. 268, 759-764

Homma, H., Sasaki, T. and Matsui, M. (1990) Chem. Pharm. Bull. 39, 1499-1503
Jakoby, W. B., Sekura, R. D., Lyon, E. S., Marcus, C. J. and Wang, J.-L. (1980) in Enzymatic Basis of Detoxication (Jakoby, W. B., ed.), vol. 2, pp. 199-228, Academic Press, New York

Jones, A. L., Hume, R., Bamforth, J. K. and Coughtrie, M. W. H. (1992) Early Hum. Dev. 28, 65-77

Laemmli, U. K. (1970) Nature (London) 227, 680-685

Lowry, O. H., Rosebrough, N. J., Farr, A. L. and Randall, R. J. (1951) J. Biol. Chem. 193, $265-275$

Merril, C. R., Goldman, D., Sedman, S. A. and Ebert, M. H. (1981) Science 211, 1437-1438

Moore, S., Thompson, E. O. P. and Nash, A. R. (1988) Aust. J. Biol. Sci. 41, 333-341

Nash, A. R., Glenn, W. K., Moore, S. S., Kerr, J., Thompson, A. R. and Thompson, E. O. P. (1988) Aust. J. Biol. Sci. 41, 507-516

Ogura, K., Kajita, J., Narahita, H., Watabe, T., Ozawa, S., Nagata, K., Yamazoe, Y. and Kato, R. (1989a) Biochem. Biophys. Res. Commun. 165, 168-174

Ogura, K., Kajita, J., Narahita, H., Watabe, T., Ozawa, S., Nagata, K., Yamazoe, Y. and Kato, R. (1989b) Biochem. Biophys. Res. Commun. 166, 1494-1500

Ogura, K., Sohtome, T., Sugiyama, A., Okuda, H., Hiratsuka, A. and Watabe, T. (1990) Mol. Pharmacol. 37, 848-854

Ozawa, S., Nagata, K., Gong, D., Yamazoe, Y. and Kato, R. (1990) Nucleic Acids Res. 18, 4001

Runge-Morris, M. and Wilusz, J. (1991) Biochem. Biophys. Res. Commun. 175, 1051-1056

Saunders, D. E., Lozon, M. M., Corombos, J. D. and Brooks, S. C. (1989) J. Steroid Biochem. 32, 749-757

Singer, S. S. (1978) Endocrinology (Baltimore) 103, 66-73

Singer, S. S., Giera, D., Johnson, J. and Sylvester, S. (1976) Endocrinology (Baltimore) 98. 963-974

Singer, S. S., Federspiel, M. J., Green, J., Lewis, W. G., Martin, V., Witt, K. R. and Tappel, J. (1982) Biochem. Biophys. Acta 700, 110-117

Sugiyama, Y., Stolz, A., Sugimoto, M., Kuhlenkamp, J., Yamada, T. and Kaplowitz, N. (1984) Biochem. J. 224, 947-953

Takikawa, H., Stolz, A. and Kaplowitz, N. (1986) FEBS Lett. 207, 193-197

Towbin, H., Staehelin, T. and Gordon, J. (1979) Proc. Natl. Acad. Sci. U.S.A. 76, 4045-4049 